\title{
Translating the Dynamics of Fictional Space: Estonian Translation of Marcel Proust's Le Temps retrouvé
}

\author{
MADLI KÜTT
}

\begin{abstract}
The article discusses the way that Proust's text constructs dynamic and static elements of fictional space, and the further dynamisation or fixation of these elements by the process of translation. The focus of the study is on how movements of fictional space and characters can change in strength, direction and manner, when translated. In other words, rather than looking for that which is "lost in translation", we are dealing with a comparison of two fictional worlds and the processes in them and between them.
\end{abstract}

Keywords: fictional worlds; poetics of space; translation; Marcel Proust; Tõnu Õnnepalu

Talking about Marcel Proust's spatiality may seem at first glance a somewhat surprising point of view, as Proust is better known as an author of time, and the title of his main novel - À la recherche $d u$ temps perdu - leaves no doubt about it. Still, ever since 1963, when Georges Poulet, a Belgian literary critic of the Geneva school of phenomenological approach, published his research called L'Espace proustien, it has been generally accepted that Proust's work deals just as much with space as it does with time, and the search for lost time is equally the search for lost space. To illustrate this, we have but to look at the most wellknown Proustian example: when the narrator of this novel dips his madeleine in the tea, it is not only about remembering, time wise, the moment of eating the cake in his youth, it is the whole town of Combray, with its church, its two sides, the houses and the good village people, that comes out of this cup of tea $(\mathrm{I}, 47)^{1}$. And from there on, all the rest of the places of his life, in Combray and elsewhere, become accessible to him, as he goes on writing about them. Thus, Poulet comes to conclude that in Proust's writing, time presents itself in the form of space (Poulet 1982: 165).

In his analysis of Proustian spatiality, Poulet stresses that it is necessary to make a difference between the notions of 'space', a general term for everything

1 Quotations from the novel will be referring to the four-volume edition and will be indicated shortly with the volume and page number. 
related to spatial features, and 'places' as concrete, personal manifestations of spatiality. Proust's places are individual, each with their own personality, a little like characters - they are often also presented in connection to particular characters of the novel - but without really forming a unified, continuing 'space'. Poulet describes Proustian space as a complex assemblage of disconnected, isolated places, as a myriad of islands floating around in the void, that come about inrelations which appear illogical and uncontrollable for the subject experiencing them (Poulet 1982: 89). On the contrary, it is the space that tends to take control of the subject by giving him a sensation of movement and instability.

Speaking about individuality of places, we need to take into consideration another important distinction, made by Samuel Beckett, whose study on Proust is based on a dichotomy of habit and transition. According to the Irish author, 'Habit' is the orderly realm of everlasting sameness, the background of succeeding routines where there is no place for death, but also no place for reality. It is the world of Françoise "the immortal cook of the Proust household who knows what has to be done, and will not tolerate any redundant activity in the kitchen" (Beckett 1999: 20). Her function is simply to be there, and to keep the world in place. Habit is the illusion of a standstill which we yearn for and fear at the same time, because even though it seems like a paradise, it "paralyses our attention", and "drugs those handmaidens of perception whose co-operation is not absolutely essential” (Beckett 1999: 20). This illusionary continuum of habit is yet constantly confronted and pierced by the moments of change and transfer from one habit to another. And, as Beckett shows, Proust's fictional world presents ample amount of these momentary openings where a habit is condemned to die and, eventually, give place to a new one, but which contain a whole other world in themselves, dangerous, painful, and enchantingly real (Beckett 1999: 22).

Such a possible opening in the space is announced to the Proustian narrator by an uncomfortable confusion in front of the unknown, which makes everything around him to move, tremble and whirl, his head spinning from the unexpected dynamics of space. His spatial discomfort is present already in the scene of insomnia at the very beginning of the novel. The narrator is trying to determine where he is, but in the darkness of the room, is unable to do so, and different rooms from his memories start to whirl around him, replacing momentarily the objects and aspects of the room he is currently in: "quand je me réveillais ainsi, mon esprit s'agitant pour chercher, sans y réussir, à savoir où j'étais, tout tournait autour de moi dans l'obscurité, les choses, les pays, les années“ (I, 6). 
Although Poulet himself makes no such connection directly, it has been argued later that this fragmentation and uncertainty of space functions namely as one of the means for the Proustian subject to absorb the reality (Fraisse 1988: 174), or as a way of accessing the depth of the inner self, le moi profond (Fraisse 1988: 178). This way of places to scatter around the fictional universe creates a certain space of possibilities, as it is shown by Anne Simon (Simon 2000:51). It is perhaps best described with her analysis of the sentence from Le Temps retrouvé: "Profonde Albertine que je voyais dormir et qui était morte" (IV, 624). Simon explains that the particular use of conjunction "et" in this sentence allows the two conditions of Albertine - being dead and being asleep - to be not just simultaneous, but to exist in the everlasting oscillation between the two possible moments (Simon 2000: 53).

Alain de Lattre has seen Proustian fiction as an interesting case in the context of the possible worlds' theory which comes forth in a comparison he draws between Proust and Leibniz (de Lattre 1979: 150). According to de Lattre, Leibniz sees these worlds as existing in parallel to one another and bound toeach other by the laws of logic, which allows us to find out the compatibility of one world with another, even to calculate the closeness or distance between them. This means, by extension, that for every world, a decision has to be made about its parameters and a fixed logical connection created from one world to another. In Proustian space of possibilities, however, the places always remain open and undecided, and thus the relation between the worlds (or places) remains open too. Things and characters are always only almost what they seem to be. There is always a "maybe", a hesitation in this construction, which is the real source of the fictional dynamics. "Le possible n'est possible que s'il le reste jusqu'au bout; que si, sur le moment du choix et de sa préférence, il lui est à la fois possible de n'être pas et d'être ${ }^{2 "}$, notes Alain de Lattre (1979: 150).

But what happens when one attempts to translate such aspace of possibilities, which does not really stand upon objects and realia, nor on the subject, who has lost control over the space, but on the flickering relationships between the two? Each individual place manifests its own tendencies for dynamics, according to its level of openness to possibility. In the following examples I am going to

2 "The possible is possible only as long as it remains possible the whole way through; only as long as, at the moment of making a choice and giving a preference, it is possible for it to be and not to be, at the same time" (my translation). 
KÜTT

discuss different manifestations of instability, openness and accessibility of the places in Le Temps retrouvé and the ways that translation changes these spatial experiences for the narrator of the novel. This last part of the Recherche was translated by an Estonian writer Tõnu Õnnepalu in 2004 and it remains to this date the only one of the seven parts entirely translated into Estonian.

It is a known practicality that the translation process often tends to interpret and concretise the open possibilities or unspoken elements in the text, and thus inclines towards more fixed and often also more visual expressions, compared to the source text. I am referring to a cognitive process known from the translation studies as the phase of deverbalisation (Balliu 2007), that is, creating a mental image (and sometimes, if need be, even an actual image) of the fictional world to be translated. Although this phase is never really absent from the writing process in its initial form (in fact, many writers are known to draw images of their created worlds), it is certainly characteristic of the translation process. The phase of deverbalisation is of particular interest here namely because during this phase of cognition and understanding, things tend to get more decided, and more fixated than they are in the original writing, which would seem to work against the effect of wavering, and would suggest gaining, rather than losing control over the fictional space.

There are several occurrences of this process in Õnnepalu's translation as well, especially towards visualisation, but perhaps more interestingly also towards fixation of movements. This can be seen for example in the "three moments of happiness" where the narrator makes his most important discovery about what it means to find time again. One of those images comes up in connection with a sound made by the central heating pipes which reminds him of a sound of boats at the sea near Balbec. Like all the moments which emerge from narrator's past with the involuntary remembrance, it has its delicate dynamics - the sun is about to set and is moving (descendait) towards the sea, and the boats are starting (commençaient $\dot{a})$ to whistle:

tandis que le soleil descendait lentement sur la mer où commençaient à crier les navires (IV, 452-453)

sellal kui aegamisi loojenev päike rippus juba üsna mere kohal, kust hakkas kostma laevade hõikeid (TA, 222)

The Estonian text shows a somewhat less dynamic image, where the verb in connection with the sun (rippuma [to hang]) now expresses a static position, rather than a movement. Thus, the translation emphasises the fixation of this moment, rather like a photograph from the past, where the sun has been 
placed in one certain point, hanging above the sea. This may be an effect of Estonian spatial declinations, which differ from French prepositions in that in addition to a placement in space, they also indicate a movement from, or to, a place. By translating the preposition (sur) rather than the verb (descendre) which he replaces with another, static one, Onnepalu's translation removes all information about the dynamics related to the object referred by this preposition.

Nevertheless, we may also notice quite a frequent occurrence of the opposite effect in Õnnepalu's translation, where the translated text gives room for more dynamics then initially present in the original. One of those moments happens when the narrator and his friend Saint-Loup are looking over the city and Saint-Loup is commenting on the irony of the situation: "Je suis sûr, me dit-il, que dans tous les grands hôtels on a dû voir les juives américaines en chemise, serrant sur leur sein décati le collier de perles qui leur permettra d'épouser un duc décavé." (IV, 338) More precisely, the change in dynamics concerns the part of the phrase referring to seeing the American Jewish ladies in their nightgowns:

on a dû voir les juives américaines en chemise, (IV, 338)

võis täna õhtul näha, kuidas mõni Ameerika juuditar öösärgi väel ringi tormab, (TA, 89, my emphasis)

The French text refers to the Jewish ladies as an object of sight, but makes no mention of any kind of a movement in connection to them. Estonian text goes further than just naming the object and adds a certain action in which the object is involved (and in this particular case, is involved with a great enthusiasm: ringi tormama [to rush around]).

A more radical change can be observed in the following example, where an idea of a full stop can become a movement too:

je voyais un pauvre permissionnaire, échappé pour six jours au risque permanent de la mort, et prêt à repartir pour les tranchées, arrêter un instant ses yeux devant les vitrines illuminées (IV, 313, my emphasis)

nägin mõnd vaest puhkusele saadetud sõdurit, pääsenud kuueks päevaks pidevast surmaohust ja valmis jälle kaevikutesse tagasi pöörduma, pilk ekslemas korraks säravatel restoraniakendel (TA 59, my emphasis)

In the French sentence, we read of a soldier in leave who has been in movement (he has momentarily escaped from death and is about to go back to war) 
KÜTT

but who has stopped, even if briefly, so that his eyes can rest on illuminated windows. Translation offers here a noticeably more dynamic situation where there is no stopping. Instead, the movement becomes even more erratic and more uncertain, giving a sense of being lost, rather than resting. In other words, when the soldier in French text might be saved briefly from all the movement and danger of war, inside ahabitual "point" that the writer has created for him, the soldier in translated text, instead, has no such escape and has to continue his battle even during vacation.

Such tendencies, in either direction, expectably intervene with Proust's poetics of space, bringing changes into the intensity and nature of the spatial processes and affecting the relations within and between individual places.

One of those relations, as we saw earlier with Beckett, comes from the distinction made between the orderly continuum of habit and the more hazardous openings for change and transition, where Proust's preference falls clearly towards the latter. The following scene from Le Temps retrouvé offers a significant metaphor for this preference. One evening during the war time in Paris, the narrator and his friend Robert de Saint-Loup are admiring the somewhat unseemly beauty of military airplanes flying in the sky above the city during a raid. While the narrator appreciates the airplanes ascending into the night, Saint-Loup invites him to pay more attention to the moment of their descent:

Mais est-ce que tu n'aimes pas mieux le moment où, définitivement assimilés aux étoiles, ils s'en détachent pour partir en chasse ou rentrer après la berloque, le moment où ils «font apocalypse », même les étoiles ne gardant plus leur place. (IV, 338)

Kuid kas sina ei armasta veel rohkem seda hetke, kui nad, olles juba lóplikult tähtede hulka ära kadunud, sööstavad äkki rünnakule või pärast häire lõpusignaali laskuma hakkavad, nii et järsku nagu ongi apokalüpsis käes, sest ka tähed taevas ei püsi enam oma kohal? (TA, 87)

Saint-Loup suggests here that his friend should like the descending airplanes more, because this is namely one of the moments of opening towards the space of possibilities and change. By breaking off from something as stable and certain as constellations of stars, among which they had become a definitive part, the airplanes destroy the illusion of order and stability and become a 
reason for a new dynamic effect of an apocalypse, giving the viewer a sensation of a change so powerful that even the stars would no longer stay in their place.

The translation deals with this image slightly differently. Firstly, the airplanes are more fully assimilated to the stars, up to the point of their complete disappearance from the scene. Thus, they cannot just break off from the constellations, because they are no longer visible as part of them, and the verb se détacher [to break off], has to be entirely left out from the translation. Instead, the airplanes are bound to do something even more extreme - to reappear on the scene, not just detach from a predetermined order of things. Secondly, their reappearance in the Estonian text happens with a concrete and sudden impulse (the Estonian words sööstavad [burst], äkki [suddenly] and järsku [abruptly] all express a dynamics that is not present in the more neutral French verbs partir [to leave], rentrer [to return], faire [to make]). On the other hand, their role as a creator of the effect of apocalypse is now much more passive - the apocalypse arrives on its own (ongi apokalüpsis käes [the apocalypsis has arrived]) rather than is being directly caused by the descending airplanes (ils "font apocalypse" [they "make the apocalypsis" [happen]]).

We can see here a two-directional process taking place in the translation: having a weaker relationship to a controlling frame which is at work in the French text, there is no longer a need to take a stand about it, neither by conforming nor by opposing to it, and therefore the translation can allow the elements of the scene to have a stronger sense of movement in space. This is clearly a moment where the translation emphasises the openness to a space of possibilities, creating an even greater accessibility to the undecided realm.

The emergence of the space of possibilities entails in itself a force, powerful enough that it can affect the narrator by taking control over him. One of such moments happens when the narrator is looking at the sky during the twilight, where everything appears to be slightly out of place. The lights in the city are lit before it is properly dark, so too early, while the sky is too light and too beautiful, and a part of it resembles the sea. This double image of the sea recalled by the evening sky becomes a metaphor of a change, terrifying but not without a possibility of bliss:

Mer en ce moment couleur turquoise et qui emporte avec elle sans qu'ils s'en aperçoivent, les hommes entraînés dans l'immense révolution de la terre, de la terre sur laquelle ils sont assez fous pour continuer leurs révolutions à eux, et leurs vaines guerres, comme celle qui ensanglantait en ce moment la France. (IV, 341) 
KÜTT

Merd, mis sellel hetkel on türkiissinine ja kannab oma turjal ka üha inimesi, kes enestele märkamata on Maa tohutust pöördumisest kaasa haaratud ja kes on küllalt hullud, et jätkata sellel pöörleval Maal omaenese pöördeid ja revolutsioone, oma asjatuid sõdu nagu see, mis parajasti Prantsusmaa verre uputab. (TA, 92)

Through this visual metaphor, the sea becomes an active and dynamic and powerful agent - it takes away the people on earth who do not even notice it happening (qui emporte avec elle sans qu'ils s'en aperçoivent, les hommes). The power of instability is dangerous, it carries away the narrator together with the people who are insane enough (ils sont assez fous) not to notice the turbulence around them but instead add to this mayhem their own revolutions and wars ( pour continuer leurs révolutions à eux, et leurs vaines guerres).

However, Proust does not give any details about the exact movement of the sea. The translation is again more explicit here - the Estonian sea lifts people up on its back (turjal) and carries them, and what's more, it does so repeatedly (üha). Thus the sea seems to be safer this time, and we could almost argue that by carrying people on its back, it is saving them from all the troubles and revolutions and from the war which is happening in France at the time.

The translation can therefore affect the forces which are at work in Proustian world, and also change their direction so that when the narrator or the characters are carried away by them, they do not end up exactly in the same places anymore. In another paragraph right before the "three moments of happiness", the narrator speaks about the route he took to go to a matinée of Guermantes, where these moments of discovery and enlightenment take place. The narrator is in a carriage which is taking him towards the matinée, and happens to be taking those exact same streets of his childhood, where he used to walk, with Françoise:

Quand j'arrivai au coin de la rue Royale, où était jadis le marchand en plein vent des photographies aimées de Françoise, il me sembla que la voiture, entraînée par des centaines de tours anciens, ne pourrait pas faire autrement que de tourner d'elle-même. (IV, 436, my emphasis)

Kui ma jõudsin Royale’i tänava nurgale, kus vanasti üks pildikaupmees müütas oues fotosid, mis Françoise'ile kangesti meeldisid, siis näis mulle, et kalessi rattad käisid ringi nii paljudest ammustest pööretest saadud hooga ja lihtsalt ei saanud muidu, kui pidid edasi veerema. (TA, 204, my emphasis)

And suddenly all the exterior obstacles are removed, the road knows of its own accord where it has to go, and the carriage makes the turns so easily, as 
if moving of its own volition, taking the narratorback to his memory-places, where he has been hundreds of times as a child. And thus it happens that the carriage, at the same time that it takes him to the matinee, which is to say, takes him towards the future, also turns back and takes the narrator to his old times, as described by Jean-Yves Tadié (1971:301). This, Tadié explains, is something that can be said about the whole Proustian novel itself: it moves forward in a river of narration, but makes constant turns towards the past.

When we look at the same paragraph in its Estonian version, the translation affects not the nature or the amount of movement, but the turning axis in which the carriage is involved. The French text makes the carriage turn horizontally, that is, around the corners of the streets, whereas the Estonian text suggests a vertical rotation of the wheels. This more detailed image of the carriage, now including its wheels which are not mentioned in the French text, brings with it a different interpretation of the word tourner [to turn] and invites the translator to change the direction of the movement, which no longer takes the narrator back, but drives him onwards (edasi [forward]).

The purpose of the dynamics in Proust's world is thus to open up a space of possibilities where another place from the past can appear together with the actual, present place. The two places are perceived as coexisting in a process that Georges Poulet calls superposition juxtaposante (Poulet 1982: 116). One of the most well known examples of such openings are the aforementioned "three moments of happiness" that the narrator encounters towards the end of Le Temps retrouvé as insights proving him the true value and meaning of literature. He experiences three times a double appearance of places - one from the past, and the other from his actual surrounding - in a direct interaction with one other. The places meet through a sensual experience: an unexpected step, a sharp sound, and a touchof a napkin on the lips call from the memory a corresponding sensation, and each one of them brings up an image of a place from the past.

However, in this fight for the right of being, the present place never fully disappears under the influence of the memory-place. Instead, the coexistence of the two places comes about asa moment of hesitation, of uncertainty and oscillation between them. In this way, the dining hall in Balbec that emerges from the touch of a napkin to the narrator's lipsdoes not completely take over the House of Guermantes where the narrator actually is, but only shakes its solidity, making the room wobble (vaciller) around him: 
KÜTT

La salle à manger marine de Balbec, avec son linge damassé préparé comme des nappes d'autel pour recevoir le coucher du soleil, avait cherché à ébranler la solidité de l'hôtel de Guermantes, d'enforcer les portes et avait fait vaciller un instant les canapés autour de moi, comme elle avait fait un autre jour pour les tables d'un restaurant de Paris. (IV, 453)

Balbeci mererestorani saal oma valgete koemustriliste laudlinadega, mis altarikatetena ootasid päikeseloojangut, oli püüdnud tühistada Guermantes'ide aadlimaja kindlust, tungida sisse selle ustest ja varjutanudki hetkeks mind piiravad diivanid, nii nagu ta kord oli teinud ühe Pariisi restorani laudadega. (TA, 222)

The dining hall (the memory-place) intrudes in the House of Guermantes with an aggressive, quivering movement, a paradoxical fight with the orderly stability of the actual place, which also happens to be one of the steadiest places in the novel. The meeting of two rooms is perceived as an encounter of two physical masses which in their opposing resistance create something similar to an earthquake:

Dans ce cas-là comme dans tous les précédents, la sensation commune avait cherché à recréer autour d'elle le lieu ancien, cependant que le lieu actuel qui en tenait la place s'opposait de toute la résistance de sa masse à cette immigration. (IV, 453)

The translation stays here too in a more visual category. The first change it brings in this direction is to mention the white colour of the tablecloths of which the original text gives no information. Similarly, the translator concentrates on the visual changes that the memory brings, providing a visual cover hiding away the objects, rather than a physical feeling of oscillation and wavering of these objects. This means also that the two rooms are not quite present simultaneously; instead, one is, even though very shortly, covering up the other one (varjutama [to overshadow]). The relationship between the two places is thus more finite, as one room is more straightforwardly aiming to cancel out (tühistada) the other one's stability, but it offers also a quieter way of intrusion, without creating a sense of losing the balance in a trembling world.

The above examples lead us to realise that translation is a process which is clearly, but not merely a language experience. In other words, there are forces that take a hold of someone who writes a text and, depending whether he is 
writing on his own account or translating the words of another, these forces are not necessarily the same. Sometimes though, these roles coincide and interact during the translation process. This is the case for the Estonian translator of Le Temps retrouvé, Tõnu Õnnepalu, as well, who is himself a writer and a poet. Despite its frequent occurrence, two things deserve to be noted in such a case: firstly, the translator has a habit of writing his own texts, and secondly, as a writer he has expressed a certain understanding of languages, especially foreign languages, and of translation. For him, translating comes not so much from a work with the dictionary, as he writes: "indeed, the dictionary has forgotten the words"3 (Õnnepalu 1985: 3), but rather from something more sensual, mystical, obscure - veiled with a curtain that cannot be lifted. With such a mindset, he has expressed his preference to translate texts from languages that he is still learning, and does not yet fully understand, because for him, lack of understanding functions as a source both for "fears, but also life force, imagination and creativity” (Õnnepalu 2005: 252). In this way, Õnnepalu, a poet who translates, becomes, when he translates, a poetic translator: someone who might let himself more easily be carried away by the dynamics of the text. It is important, however, to remember that it is not necessarily translator's task to keep these forces rigidly in place, but rather to follow them in his turn, as is argued by British professor in European literatures and translation, Clive Scott: "Translation attempts neither to reconcile languages nor to demonstrate their differences as inalienable, as measures of cultural identity or indelibility. [...] More important is the entirely personal enterprise of alterity: I confront another to become myself; this is neither the concealment of other in self, nor the preservation of other in self, but the transformation of other into self, where the transformative process itself is what counts, is what must remain visible, is both process and project." (Scott 2013: 3-4) Thus, the translated Proustian places will not only have their own rhythm and dynamic effects, as we have seen, but they will also relate to each other in different ways and therefore build up a universe which may or may not respond to the same laws of fragmentation, possibility, and connection.

\section{Madli Kütt}

madli.kytt@gmail.com

Tuule 5-3a

51009 Tartu

EESTI / ESTONIA

3 My translation. The verse from Õnnepalu's poem reads as: "tõesti sõnaraamat on sõnad unustanud". 
KÜTT

\section{References}

Balliu, C. 2007. Cognition et déverbalisation. - Meta: journal des traducteurs / Meta: Translators' Journal, vol 52, No 1, p.3-12. - http://id.erudit.org/iderudit/014714ar (21.01.2015).

Beckett, S. 1999. Proust. London: John Calder Publishers.

Fraisse, L. 1988. Le Processus de la création chez Marcel Proust. Paris: José Corti.

Lattre, A. de 1979. La Doctrine de la réalité chez Proust. Vol. I. Paris: José Corti.

Õnnepalu, T. 1985. Täna pean videvikutundi. - Jõeäärne maja. Tallinn: Kommunist. Õnnepalu, T. 2005. Saksa(maa) Prantsuse peeglis. - Looming, 2005, No. 2, 252-259.

Poulet, G. 1982. L'Espace proustien. Paris: Gallimard.

Proust, M. A la recherche du temps perdu. Vols. I-IV. Paris: Gallimard, Collection "Bibliothèque de la Pléiade".

Proust, M. 2004. Taasleitud aeg. Transl. Tõnu Õnnepalu. Tallinn: Eesti Keele Sihtasutus.

Simon, A. 2000. Le réel retrouvé. Paris: Presses Universitaires de France.

Scott, C. 2012. Literary Translation and the Rediscovery of Reading. Cambridge: Cambridge University Press. 